\title{
Improvement of Heterogeneous Sensitizer Photobactericidal Activity by Elongation of Linker between Phthalocyanine and Silica Gel Support
}

\author{
Nina A. Kuznetsova, ${ }^{a}$ Olga A. Yuzhakova, ${ }^{a}$ Marina G. Strakhovskaya, ${ }^{\mathrm{b}}$ \\ Ludmila K. Slivka, ${ }^{a}$ Oleg L. Kaliya, ${ }^{a}$ and Evgeny A. Lukyanets ${ }^{a}$ \\ ${ }^{a}$ Organic Intermediates and Dyes Institute, 123995 Moscow, Russia \\ ${ }^{\mathrm{b} D e p a r t m e n t ~ o f ~ B i o p h y s i c s, ~ F a c u l t y ~ o f ~ B i o l o g y, ~ L o m o n o s o v ~ M o s c o w ~ S t a t e ~ U n i v e r s i t y, ~} 119991$ Moscow, Russia \\ ${ }^{\circledR}$ Corresponding author E-mail: lab32@niopik.ru
}

\begin{abstract}
Aminopropyl groups on the surface of aminopropylated silica gel were lengthened by grafting of additional propyleneimine units and applied to immobilize singlet oxygen sensitizers of cationic phthalocyanine series. The absorption and fluorescence spectra, generation of singlet oxygen and photobactericidal activity were studied for aqueous suspensions of these new heterogeneous systems. The effect of spacer length upon absorption and emission spectra as well as on efficacy of singlet oxygen generation by tethered phthalocyanines was not observed. However, the photobactericidal function of the supported phthalocyanines was markedly increased along with length of spacer.
\end{abstract}

Keywords: Phthalocyanine, heterogeneous sensitizer, photobactericidal effect.

\section{Увеличение фотобактерицидной активности гетерогенных сенсибилизаторов путем УАлинения спейсера, связывающего фталоцианин с носителем}

\author{
Н. А. Кузнецова, ${ }^{a}$ О. А. Южакова, ${ }^{a}$ М. Г. Страховская, ${ }^{\text {b }}$ А. К. Сливка, ${ }^{a}$ \\ О. ᄉ. Калия, ${ }^{a}$ Е. А. Аукъянец \\ “ФГУП Государственный научный иеентр “НИОПИК”, 123995 Москва, Россия \\ ${ }^{\mathrm{b}}$ Московский государственный университет им. М.В. Ломоносова, 119991 Москва, Россия \\ ${ }^{\circledR}$ E-mail: lab32@niopik.ru
}

\begin{abstract}
Проведено наращчивание аминопропильных групп аминопропилированного силикагеля дополнительныли пропиламинными фрагментами и прививка к ним сенсибилизаторов синглетного кислорода из ряда катионньх фталоцианинов. Увеличение длины спейсера, связывающего фталоциианин с носителем, не оказывает влияния на спектрально-люминесцентные свойства и генераџию активной фазой синглетного кислорода, однако фотобактерицидная активность гетерогенного сенсибилизатора при этом значительно возрастает.
\end{abstract}

Ключевые слова: Фталоцианин, гетерогенный сенсибилизатор, фотобактерицидный эффект. 


\section{Introduction}

It is well known that the photosensitizers in the presence of light and oxygen are able to destroy microorganisms due to photodynamic effect. The photodynamic effect was first described by Raab for acridine dyes more than a century ago. ${ }^{[1]}$ It was shown later that efficiency of microbial cells photodynamic inactivation depends on both the structure of the dye and the morphology of the microorganism. Thus, Gram-positive bacteria are very sensitive to the photodynamic action of a variety of photosensitizers, whereas Gramnegative bacteria display a resistance to photosensitization. ${ }^{[2,3]}$ Among photosensitizers, high photodisinfection activity occurs for positively charged ones, because positive charge endows sensitizer molecule high affinity to negatively charged outer membrane of cell, inducing damage that enhances the penetration of the photosensitizer. ${ }^{[3]}$

The mechanism of the photodynamic effect involves damage to bacterial cells by reactive oxygen species, mainly singlet oxygen, generated by sensitizers in photoexcited state. The photodynamic inactivation of microorganisms is a promising approach for disinfection of water ${ }^{[4]}$ and blood products. ${ }^{[5]}$ In most studies, for this purpose watersoluble photosensitizers were tested. It was established that photodynamic disinfection of aqueous systems by water-

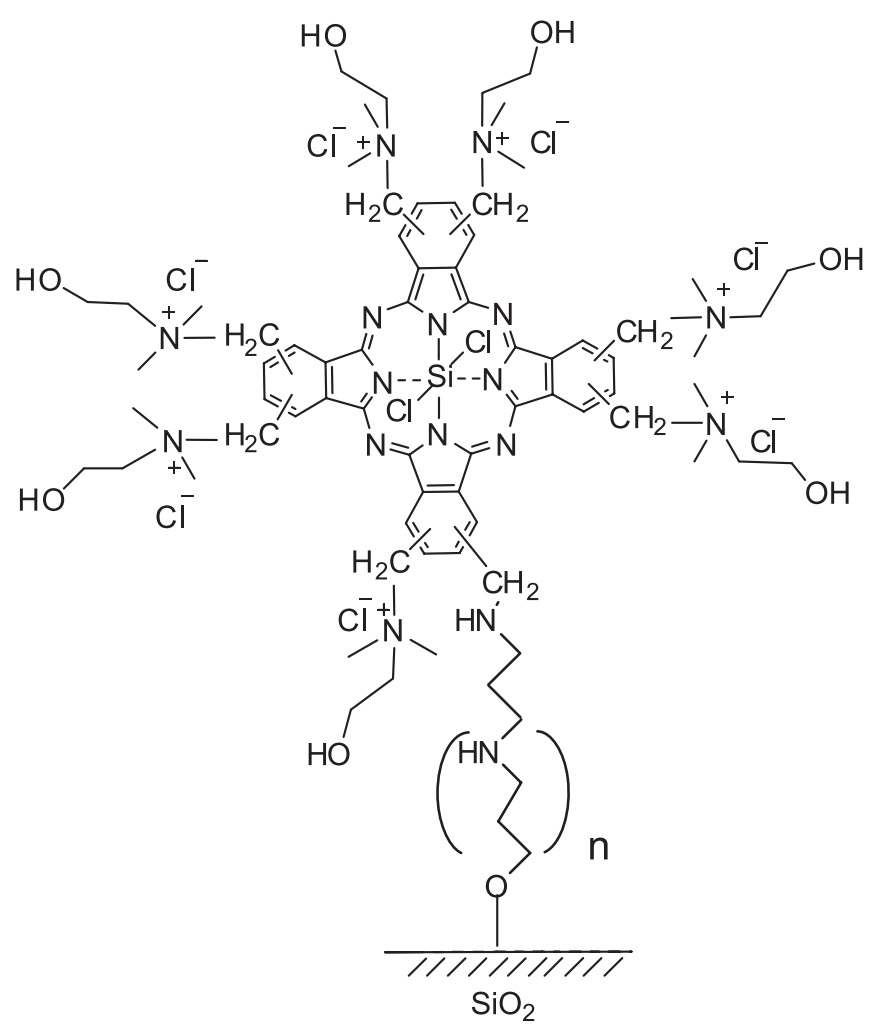

1P-250/SiPc ( $\mathrm{n}=0$, on Diasorb-250 amine)

1P-750/SiPc ( $\mathrm{n}=0$, on Diasorb-750 amine)

2P-250/SiPc ( $\mathrm{n}=1$, on Diasorb-250 amine)

2P-750/SiPc ( $\mathrm{n}=1$, on Diasorb-750 amine)

4P-250/SiPc ( $\mathrm{n}=3$, on Diasorb-250 amine)

4P-750/SiPc ( $\mathrm{n}=3$, on Diasorb-750 amine) soluble sensitizers is rather efficient. However, removal of water-soluble dyes and their photoproducts from treated solutions is extremely difficult. Therefore, the use of heterogeneous photosensitizers where dyes are immobilized onto solid materials might be more promising because heterogeneous photosensitizers can be easily separated from the solutions by centrifugation or filtration.

Unfortunately, efficiency of microorganism photoinactivation after sensitizer immobilization markedly drops, because attached one cannot penetrate into bacterial cell and generates the reactive oxygen species outside it. So, the search of heterogeneous sensitizers with improved photobactericidal activity is urgent.

Recently we have developed a new heterogeneous photosensitizer in which zinc or aluminum phthalocyanine, tetrasubstituted at 3,6 positions with modified phenylsulphanyl group, was immobilized by covalent bonding on aminopropyl silica. ${ }^{[6]}$ It was shown that upon photoexcitation, silica gel-bound phthalocyanines produce singlet oxygen and display activity against bacteria $E$. coli and viruses, polio virus type 1 LSc2ab and phage MS-2 particularly. ${ }^{[6,7]}$ The photobiocidal activity of positively charged photosensitizer was markedly higher than that of negatively charged or neutral ones. This may be due to more effective interaction of the negatively charged bacteria with positively charged dye.

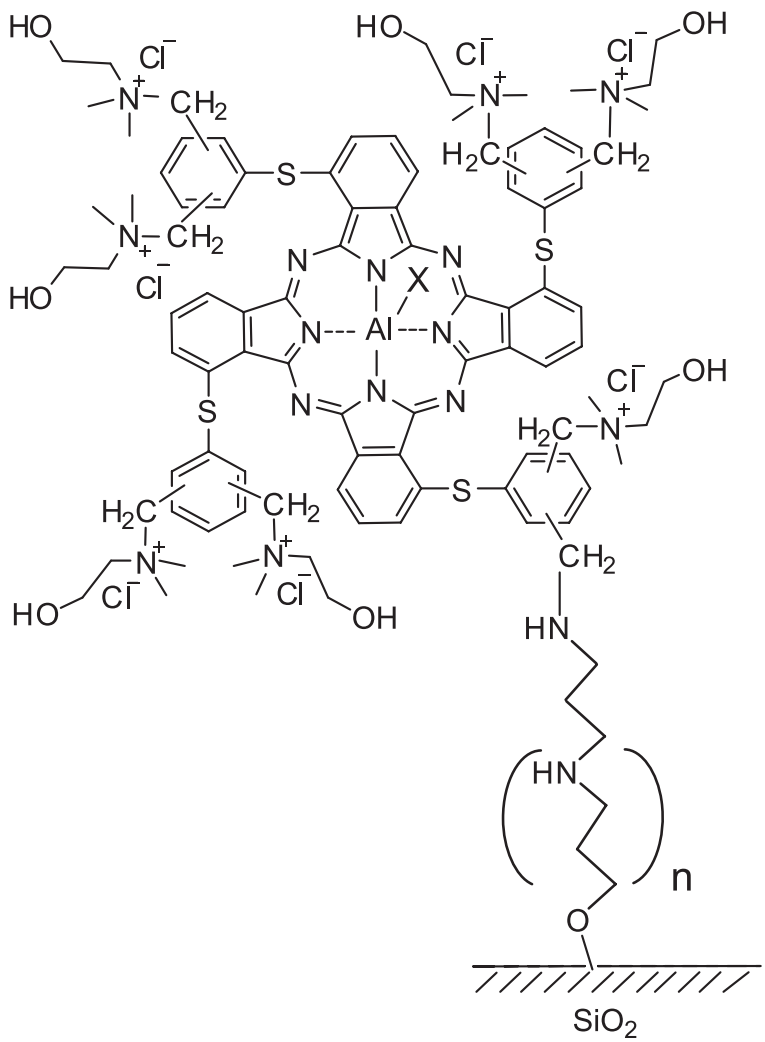

1P-250/AIPc ( $\mathrm{n}=0$, on Diasorb-250 amine)

2P-250/AIPc ( $\mathrm{n}=1$, on Diasorb-250 amine)

Figure 1. Structures and assignation of heterogeneous sensitizers. 
[6] The virus inactivation in water is a two-step and involves the sorption of virus on a heterogeneous sensitizer particles and photodynamic inactivation of adsorbed virus. ${ }^{[6,7]}$ It was found later that pore size affect the sensitizer penetration in pores, and phthalocyanine molecules located on the surface are more efficient for $E$. coli inactivation than the dye molecules located inside pores, ${ }^{[8]}$ whereas accumulation of both the active phase (dye) and virus inside pores provides conditions for efficient photovirucidal activity. ${ }^{[9]}$

This paper describes the effect of length of spacer between phthalocyanine and silica gel support upon heterogeneous sensitizer photobactericidal activity. It should be mentioned that recently a more powerful catalytic effect on the photooxidation of 1,5-dihydroxynaphthalene for protoporphyrin IX, immobilized with longer spacer chain, was reported. ${ }^{[10]}$ The present contribution reports on modification of the aminopropyl groups on silica gel by stepwise treatment with 3-bromopropylamine hydrobromide followed by covalent bonding of phthalocyanine sensitizer to the elongated tether. Figure 1 shows the structures of the heterogeneous system synthesized and studied in this work. The spectral, fluorescent properties and photosensitizing tendencies of new heterogeneous sensitizers were investigated.

\section{Experimental}

Electronic absorption spectra were recorded with Hewlett Packard 8453 spectrophotometer, fluorescence excitation and emission spectra - with Cary Eclipse spectrofluorimeter. The ${ }^{1} \mathrm{H}$ NMR spectra were measured using the Varian $(200 \mathrm{MHz})$ with the solvent signal as internal standard. Elemental analyses were done by standard microanalysis methods.

\section{Materials}

The aminopropyl silica gels Diasorb-250 amine and Diasorb750 amine (ZAO "BioChemMakST", Russia) had following parameters: pore diameter 25 and $75 \mathrm{~nm}$, grain size 100-200 and 40-100 $\mu \mathrm{m}$, surface area 100 and $40 \mathrm{~m}^{2} \cdot \mathrm{g}^{-1}$, correspondingly, 3 -aminopropyl group loading of $0.4 \mathrm{mmol} \cdot \mathrm{g}^{-1}$. The silica gel was washed with water and dried at $100-105{ }^{\circ} \mathrm{C}$ before use for aminopropyl group modification and phthalocyanine grafting. The use was made of $\mathrm{SiCl}_{2} \mathrm{Pc}$ (Aldrich), the singlet oxygen trap 1,3diphenylisobenzofuran (DPBF) (Fluka), sodium dodecyl sulfate (SDS) (Pancreac, Pharm grade, Spain), 3-bromopropylamine hydrobromide (Alfa Aesar, Great Britain). Cationic water-soluble ${ }^{1} \mathrm{O}_{2}$ trap 9,10-bis-(4-(trimethylammonio)phenyl)anthracene dihydrochloride (BPAA) was synthesized as described in paper. ${ }^{[11]}$

\section{Synthesis}

(3)-Tetrakis[di(chloromethyl)phenylsulphanyl]phthalocyaninatoaluminum hydroxide, AlPc $(\mathrm{SPh})_{4} \mathrm{Clm}_{8}$. Aluminum tetra-(3phenylsulphanyl)phthalocyanine was prepared and characterized as described in ${ }^{[12]}$. Synthesis of its chloromethylated derivative was accomplished as given in the patent ${ }^{[13]}$. (3)-Tetrakis[di(chloromethyl)phenylsulphanyl]phthalocyaninato aluminum hydroxide, AlPc(SPh) ${ }_{4} \mathrm{Clm}_{8}$. Yield $84.9 \%$. Found: C 55.33, H 3.74, N 7.62, S $8.83, \mathrm{Cl} 20.02 \% . \mathrm{C}_{64} \mathrm{H}_{41} \mathrm{AlCl}_{8} \mathrm{~N}_{8} \mathrm{OS}_{4}$ requires $\mathrm{C} 55.82, \mathrm{H} 3.00, \mathrm{~N}$ 8.13, S 9.31, Cl 20.59. UV-vis (DMF) $\lambda_{\max } \mathrm{nm:} \mathrm{715.}{ }^{1} \mathrm{H}$ NMR ([D $]$ DMSO) $\delta_{\mathrm{H}}$ ppm: 7-10.2 (br, ArH), $5.0(\mathrm{br}, \mathrm{ClmH})$.

Octakis(chloromethyl)phthalocyaninato silicon dichloride, $\mathrm{SiPcClm}_{8}$ was prepared and characterized as described in ${ }^{[13]}$. Yield $0.45 \mathrm{~g}$ (68.7\%). Found: C 47.51, H 2.82, N 10.85, Cl 34.71\%. $\mathrm{C}_{40} \mathrm{H}_{24} \mathrm{Cl}_{10} \mathrm{~N}_{8} \mathrm{Si}$ requires $\mathrm{C} 48.07, \mathrm{H} 2.42, \mathrm{~N} 11.21, \mathrm{Cl} 35.47$. UV-vis
(DMF) $\lambda_{\max }$ nm: 692. ${ }^{1} \mathrm{H}$ NMR ([D $]$ DMSO) $\delta_{\mathrm{H}} \mathrm{ppm}: 7-10.1(\mathrm{br}$, ArH), 5.4 (br, ClmH).

Octakis $[N-(2-$ hydroxyethyl $)-N, N$-dimethylammoniummethyl]phthalocyaninato silicon dichloride, SiPcChol $.0 .23 \mathrm{~g}$ of octakis-(chloromethyl)phthalocyaninato silicon dichloride was stirred $0.5 \mathrm{~h}$ in $2 \mathrm{ml}$ 2-dimethylaminoethanol at $100{ }^{\circ} \mathrm{C}$. The reaction mixture was filtered, precipitate was washed with hot acetone, twice reprecipitated from methanol by acetone and dried several hours in vacuum at $80-90{ }^{\circ} \mathrm{C}$. Yield $0.2 \mathrm{~g}(51.8 \%)$. Found: $\mathrm{N} 12.65 \%$. $\mathrm{C}_{72} \mathrm{H}_{112} \mathrm{Cl}_{10} \mathrm{~N}_{16} \mathrm{O}_{8} \mathrm{Si}$ requires $\mathrm{N}, 13.08$. UV-vis $\left(\mathrm{H}_{2} \mathrm{O}\right)$ $\lambda_{\max }$ nm: 699. ${ }^{12} \mathrm{H}$ NMR $\left(D_{2} \mathrm{O}\right) \delta_{\mathrm{H}} \mathrm{ppm}$ : 7-10.2 (br, ArH), $5.3\left(16^{2} \mathrm{H}\right.$, br, $\left.\mathrm{ArCH}_{2} \mathrm{~N}\right), 4.04\left(16 \mathrm{H}, \mathrm{br}, \mathrm{CH}_{2} \mathrm{O}\right), 3.5\left(16 \mathrm{H}, \mathrm{br}, \mathrm{CH}_{2} \mathrm{~N}\right), 3.1(48$ $\mathrm{H}, \mathrm{br}, \mathrm{CH}_{3}$ ).

Heterogeneous sensitizer 1P-250/SiPc (Diasorb-250 amine loaded by $\left.5 \mu \mathrm{mol} \cdot \mathrm{g}^{-1} \mathrm{SiPcChol}_{7}\right)$. Diasorb-250 amine $(1 \mathrm{~g})$ was added to a DMF solution of $\mathrm{SiPcClm}_{8}\left(5 \cdot 10^{-6} \mathrm{~mol}\right.$ in $\left.20 \mathrm{~mL}\right)$. The mixture was stirred at $80-85{ }^{\circ} \mathrm{C}$ during $1-2 \mathrm{~h}$. For this time, the solution was completely decolorized and silica gel became deep green. Then, 2-dimethylaminoethanol $\left(5 \cdot 10^{-3} \mathrm{~mol}\right)$ was added, and the mixture stirring was continued at $80-85^{\circ} \mathrm{C}$ during $1 \mathrm{~h}$. After cooling to room temperature, the product was filtered, washed with water and dried at $80-90{ }^{\circ} \mathrm{C}$.

Heterogeneous sensitizer 2P-250/SiPc (Diasorb-250 amine, once modified by treatment with 3-bromopropylamine hydrobromide and then loaded by $\left.5 \mu \mathrm{mol} \cdot \mathrm{g}^{-1} \mathrm{SiPcChol}_{7}\right)$.

Modification of Diasorb. Diasorb-250 amine (5 g) was added to a dioxane solution of 3-bromopropylamine hydrobromide $(1 \mathrm{~g}$ in $20 \mathrm{~mL}$ ). The mixture was stirred at $90-95^{\circ} \mathrm{C}$ during $2 \mathrm{~h}$. Then, the suspension was cooled to room temperature. The treated silica gel was filtered, washed with water, aqueous alkali and once more with water until the neutral $\mathrm{pH}$ of filtrate. Modified silica gel, 2P-250, was dried at $80-90^{\circ} \mathrm{C}$.

Silica gel 2P-250 ( $1 \mathrm{~g}$ ) was added to DMF solution of $\mathrm{SiPcClm}_{8}$ $\left(5 \cdot 10^{-6} \mathrm{~mol}\right.$ in $\left.20 \mathrm{~mL}\right)$. The mixture was stirred at $80-85^{\circ} \mathrm{C}$ during 1-2 h. For this time, the solution was completely decolorized and silica gel became deep green. Then, $N, N$-dimethylaminoethanol $\left(5 \cdot 10^{-3} \mathrm{~mol}\right)$ was added, and the mixture stirring was continued at $80-85^{\circ} \mathrm{C}$ during $1 \mathrm{~h}$. After cooling to room temperature, the product was filtered, washed with water and dried at $80-90^{\circ} \mathrm{C}$.

Synthesis of heterogeneous sensitizer 4P-250/SiPc. Diasorb-250 amine $(5 \mathrm{~g})$ was added to a dioxane solution of 3-bromopropylamine hydrobromide $(1 \mathrm{~g}$ in $20 \mathrm{~mL})$. The mixture was stirred at $90-95^{\circ} \mathrm{C}$ during $2 \mathrm{~h}$. Then, the suspension was cooled to room temperature. The treated silica gel was filtered, washed with water, aqueous alkali, once more with water until the neutral $\mathrm{pH}$ of filtrate and dried at $80-90{ }^{\circ} \mathrm{C}$. This treatment was reapplied three times to yield 4P-250.

Silica gel 4P-250 (1 g) was added to a DMF solution of $\mathrm{SiPcClm}_{8}\left(5 \cdot 10^{-6} \mathrm{~mol}\right.$ in $\left.20 \mathrm{~mL}\right)$. The mixture was stirred at $80-85^{\circ} \mathrm{C}$ during 1-2 h. For this time, the solution was completely decolorized and silica gel became deep green. Then, $N, N$-dimethylaminoethanol $\left(5 \cdot 10^{-3} \mathrm{~mol}\right)$ was added, and the mixture stirring was continued at $80-85^{\circ} \mathrm{C}$ during $1 \mathrm{~h}$. After cooling to room temperature, the product was filtered, washed with water and dried at $80-90{ }^{\circ} \mathrm{C}$.

Synthesis of heterogeneous sensitizers $1 P-750 / S i P c, 2 P-750 /$ $\mathrm{SiPc}$ and $4 \mathrm{P}-750 / \mathrm{SiPc}$ was conducted similarly, using Diasorb-750 amine instead of Diasorb-250 amine.

Synthesis of heterogeneous sensitizer 1P-250/AlPc (Diasorb250 amine loaded by $\left.5 \mu \mathrm{mol} \cdot \mathrm{g}^{-1} \mathrm{AlPc}(\mathrm{SPh})_{4} \mathrm{Chol}_{7}\right)$ was conducted as $1 \mathrm{P}-250 / \mathrm{SiPc}$, using $\mathrm{AlPc}(\mathrm{SPh})_{4} \mathrm{Clm}_{8}$ instead of $\mathrm{SiPcClm}_{8}$.

Synthesis of heterogeneous sensitizer 2P-250/AlPc was conducted as $2 \mathrm{P}-250 / \mathrm{SiPc}$, using $\mathrm{AlPc}(\mathrm{SPh})_{4} \mathrm{Clm}_{8}$ instead of $\mathrm{SiPcClm}{ }_{8}$.

\section{Methods}

In water, particles of heterogeneous sensitizers quickly precipitate. So for study the fine aqueous suspensions sustained 


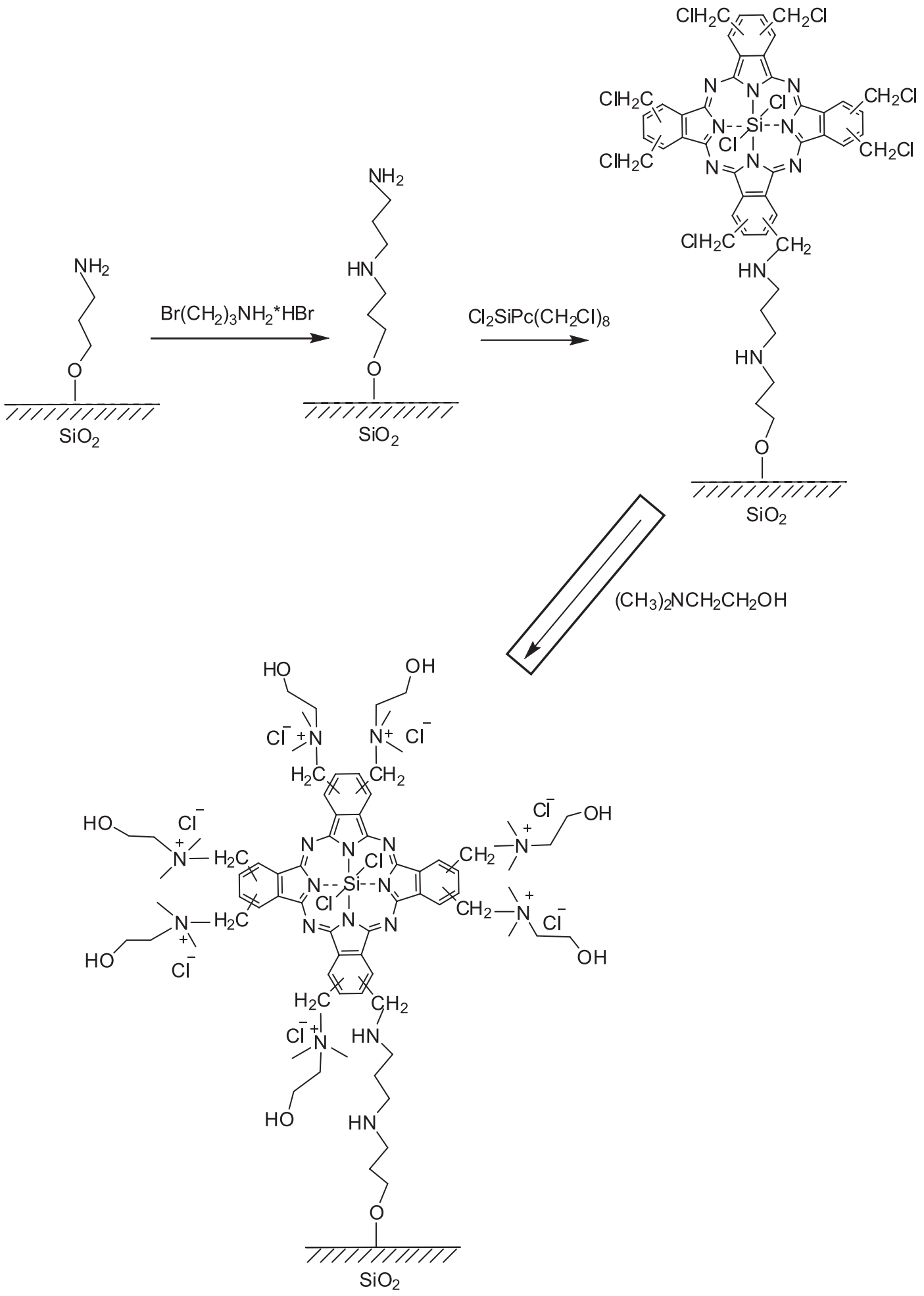

Scheme 1. Synthesis of the $2 \mathrm{P}-250 / \mathrm{SiPc}\left(\mathrm{SiO}_{2}=\right.$ Diasorb-250 amine $)$ and $2 \mathrm{P}-750 / \mathrm{SiPc}\left(\mathrm{SiO}_{2}=\right.$ Diasorb-750 amine $)$.

by SDS were used. The fine suspensions were prepared as follows. The initial powders were carefully crushed with a porcelain pestle, suspended in $0.2 \mathrm{M}$ SDS and then sonicated during $15 \mathrm{~min}$ in ultrasonic water bath. After sonication, fine dispersions were obtained, which were stable in water during hours. To reduce influence of light scattering and reabsorption of fluorescence by dye molecules, suspensions were employed with the absorbance $0.20-0.25$ at the long wavelength absorption maximum of phthalocyanine. Suspensions of unloaded Diasorb-250 amine were used as references. Samples were placed into $10 \mathrm{~mm}$ rectangular quartz cells. Fluorescence was detected at the right angle to the excitation beam. Fluorescence quantum yield for $\mathrm{SiPcChol}_{8}$ in water was determined as described in. ${ }^{[14]}$

\section{Singlet Oxygen Detection}

Quantum yield of singlet oxygen production by $\mathrm{SiPcChol}_{8}$ in aqueous solution was determined as described in ${ }^{[15]}$ with the BPAA water-soluble cationic singlet oxygen trap.

Photosensitized generation of singlet oxygen by heterogeneous sensitizers was studied for their aqueous suspensions, sustained by $\operatorname{SDS}(0.2 \mathrm{M})$. In these conditions the use of 1,3- 
diphenylisobenzofuran (DPBF) singlet oxygen trap was possible ${ }^{[16]}$ and preferable due to higher constant of DPBF oxygenation by singlet oxygen. To fine suspensions of heterogeneous photosensitizers in $0.2 \mathrm{M}$ aqueous solutions of SDS the concentrated acetone solutions of DPBF were added. The final acetone concentration in the suspensions was $3 \%$, the concentration of DPBF was $\sim 40 \mu \mathrm{M}$. Suspensions were placed into $1 \mathrm{~cm}$ rectangular spectroscopic cells and irradiated by tungsten lamp with stabilized DS power supply $(200 \mathrm{~W})$ through the cut-off glass filter KC-15 (transmitted red light with $\lambda \geq 640 \mathrm{~nm}$ ). An interference filters of $710 \pm 25 \mathrm{~nm}$ (for SiPc series) or $750 \pm 25 \mathrm{~nm}$ (for AlPc series) were additionally placed in the light path, the irradiation fluence rates were $0.46 \mathrm{~W}$ and $0.53 \mathrm{~W}$, correspondingly. Unfortunately, due to suspension light scattering we were unable to estimate the number of photons absorbed by sensitizer and evaluate the singlet oxygen quantum yields. Based on DPBF photobleaching rates, which are directly proportional to the rates of singlet oxygen production, the relative sensitizer efficiencies in singlet oxygen generation were estimated.

\section{Photosensitized Inactivation of Bacteria}

A bacterial bioluminescent test system based on the genetically engineered bioluminescent strain E. coli K-12 TG1, which emits bioluminescence due to the complete cloned lux-operon (commercially available biosensor Ecolum, Russia), was used for determination of photobactericidal activity of heterogeneous photosensitizers. The method is based on the correlation between photosensitized bioluminescence quenching and inactivation of bacterial colony forming units. ${ }^{[17]}$ Bioluminescence was measured using the Sirius Smart Line TL (Titertek, USA) luminometer. Heterogeneous photosensitizers $(20 \mathrm{mg})$ with attached phthalocyanines $\left(5 \mu \mathrm{mol} \cdot \mathrm{g}^{-1}\right)$ were added to $5 \mathrm{~mL}$ bacterial suspensions, containing $3 \cdot 10^{7}$ bacterial cells per milliliter. The phthalocyanine concentration in the suspensions was $20 \mu \mathrm{M}$. The experimental and control samples were preincubated during $10 \mathrm{~min}$ at $20-22{ }^{\circ} \mathrm{C}$ under vigorous stirring. The experimental samples were then irradiated (the height of irradiated sample was $1 \mathrm{~cm}$ ) under continued stirring during $30-90 \mathrm{~min}$ by halogen lamp through a water filter (light fluence rate was $50 \mathrm{~mW} / \mathrm{cm}^{2}$ ). After illumination, stirring was interrupted, and photosensitizer was precipitated. The supernatant containing bacterial cells $(2 \mathrm{~mL})$ was used for bioluminescence measurements. The control samples were treated similarly without irradiation.

\section{Results and Discussion}

In our previous papers ${ }^{[6-9]}$ for the covalent bonding of phthalocyanines to solid support the reaction of phthalocyanine polychloromethyl derivatives with the amino functions on the aminopropyl silica was used by us. This approach gave heterogeneous sensitizers with dye molecules tethered to silica through one propyleneimine spacer. In the present work the heterogeneous structures with longer spacers were synthesized by initial treatment of aminopropyl silica gel with 3-bromopropylamine hydrobromide in dioxane at $90-95{ }^{\circ} \mathrm{C}$ with subsequent washing of its excess by aqueous alkali (examples for $2 \mathrm{P}-250 / \mathrm{SiPc}$ and $2 \mathrm{P}-750 / \mathrm{SiPc}$ are given on Scheme 1). This procedure may be reiterated to obtain any number of propyleneimine units in the chain. Then polychloromethylated phthalocyanine was chemically bounded to spaceramino groupsin $N, N$ '-dimethylformamide at $80-85{ }^{\circ} \mathrm{C}$. In the present work silicon phthalocyanine or aluminum tetraphenylsulphanylphthalocyanine with eight chloromethyl substituents were used for grafting.
After $0.5-1 \mathrm{~h}$ stirring the complete decolouration of solutions was observed, showing that all phthalocyanine molecules were consumed in the reaction. Simultaneously, silica gel with attached phthalocyanine molecules gained deep green colour. It should be mentioned that attachment of chloromethylated phthalocyanines is possible both to primary and secondary amine group of spacer, however, considering the steric reasons, the terminal primary one will be preferable. Finally, the reaction of the immobilized chloromethyl substituted phthalocyanines with $N, N$-dimethylaminoethanol yields derivatives with positively charged $N$-(2-hydroxyethyl)$N, N$-dimethylammoniummethyl groups (Scheme 1). One- and three-fold treatment of the aminopropyl silica with 3-bromopropylamine gives chains of two and four propyleneimine groups (2P and 4P structures, Figure 1). Thus, three series of sensitizers have been synthesized: first series included $\mathrm{SiPcChol}_{7}$, anchored to Diasorb-250 amine by one, two and four propyleneimine groups (1P-250/SiPc, 2P-250/SiPc, 4P-250/SiPc, Figure 1), in the second series Diasorb-750 amine was used as support (sensitizers 1P-750/ SiPc, 2P-750/SiPc and 4P-750/SiPc, accordingly), and third one consisted of 1P-250/AlPc and 2P-250/AlPc with linked aluminum phthalocyanine derivative $\mathrm{AlPc}(\mathrm{SPh})_{4} \mathrm{Chol}_{7}$.

Visually, the color intensity of samples decreases notably with an increase in the support pore size from $25 \mathrm{~nm}$ (Diasorb-250 amine) to $75 \mathrm{~nm}$ (Diasorb-750 amine). This indicates that phthalocyanine is predominantly located inside the pores of a support with $75 \mathrm{~nm}$ pores and on the surface of a support with $25 \mathrm{~nm}$ pores. The effect of the spacer length on the distribution of phthalocyanine between surface and pores in all series of sensitizers was not observed.

It is well known that phthalocyanines due to strong $\pi-\pi$ interactions and the flatness of the aromatic core are inclined to aggregation, which is recognized by broadening of the $Q$ band in their optical spectra. However, the unbound $\mathrm{SiPcChol}_{8}$ both in aqueous solution without additives and in the presence of $0.2 \mathrm{M}$ sodium dodecyl sulfate (SDS) has a typical for phthalocyanine monomers absorption spectra with sharp and intense $Q$ bands and well resolved vibrational satellites. Figure 2 illustrates the absorption spectra of the diluted suspensions, obtained by sonication in $0.2 \mathrm{M}$ aqueous SDS solutions of three $\mathrm{SiPcChol}_{7}$-containing heterogeneous photosensitizers with one, two and four propyleneimine units in spacer, connecting phthalocyanine and support, in comparison with the spectrum of free $\mathrm{SiPcChol}_{8}$. It is seen that immobilized dye also shows monomeric behaviour - both maxima (699 nm, Table 1) and shape (Figure 2) of heterogeneous sample $Q$ bands are very similar to those of free dye. The exclusive monomeric state of $\mathrm{SiPcChol}_{8}$ is caused by axial ligands at central atom and ramified substituents preventing a close packing. It is well known that monomerization of sensitizer is one of the key factors for high photodynamic activity so far as aggregation decreases the efficiency of ${ }^{1} \mathrm{O}_{2}$ photogeneration. ${ }^{[18]}$ In addition, absence of $Q$ band broadening for immobilized $\mathrm{SiPcChol}_{7}$ suggests electronic structure of phthalocyanine molecule is not perturbed by interaction with the carrier. On the whole, obtained results show that effect of spacer length upon phthalocyanine electronic levels and spectra was not observed. 
Table 1. Main absorption $\left(\lambda_{\max }{ }^{\mathrm{A}}\right)$ and fluorescence $\left(\lambda_{\max }^{\mathrm{F}}\right)$ maxima of the heterogeneous photosensitizers in aqueous suspensions containing 0.2 M SDS in comparison with those of unbound $\mathrm{SiPcChol}_{8}$ in the same medium.

\begin{tabular}{ccc}
\hline Sample & $\lambda_{\max }{ }^{\mathrm{A}}, \mathrm{nm}$ & $\lambda_{\max }{ }_{\mathrm{F}}^{\mathrm{F}}, \mathrm{nm}$ \\
\hline SiPcChol & 699 & 703 \\
1P-250/SiPc & 699 & 703 \\
2P-250/SiPc & 699 & 703 \\
4P-250/SiPc & 699 & 703 \\
1P-750/SiPc & 699 & 703 \\
2P-750/SiPc & 698 & 703 \\
4P-750/SiPc & 698 & 703 \\
1P-250/AlPc & 736 & 731 \\
2P-250/AlPc & 736 & 731 \\
\hline
\end{tabular}

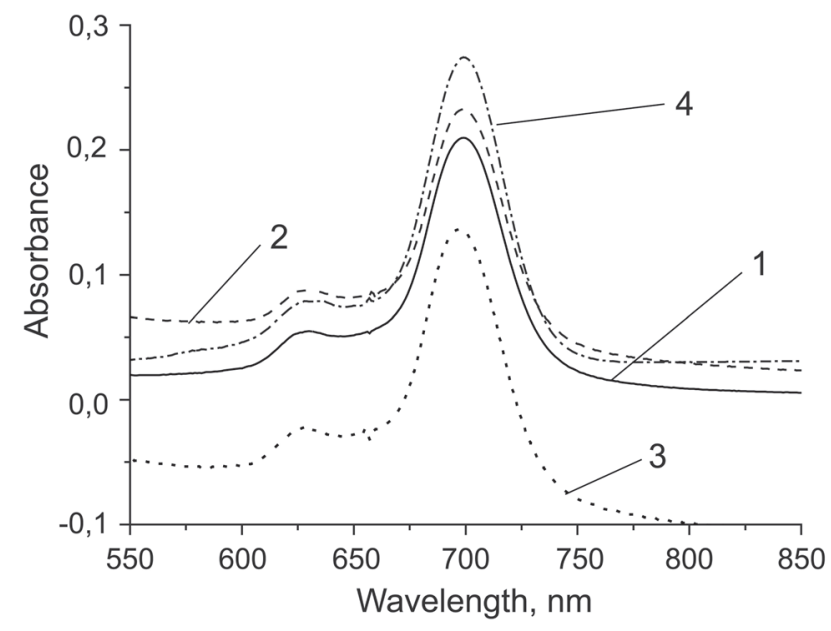

Figure 2. Electronic absorption spectra of the diluted suspensions of $1 \mathrm{P}-750 / \mathrm{SiPc}(1), 2 \mathrm{P}-750 / \mathrm{SiPc}(2), 4 \mathrm{P}-750 / \mathrm{SiPc}(3)$ and free $\mathrm{SiPcChol}_{8}(4)$ in $0.2 \mathrm{M}$ aqueous SDS.

In Figure 3 as an example, the normalized absorption, emission and fluorescence excitation spectra of 4P-250/SiPc are represented.

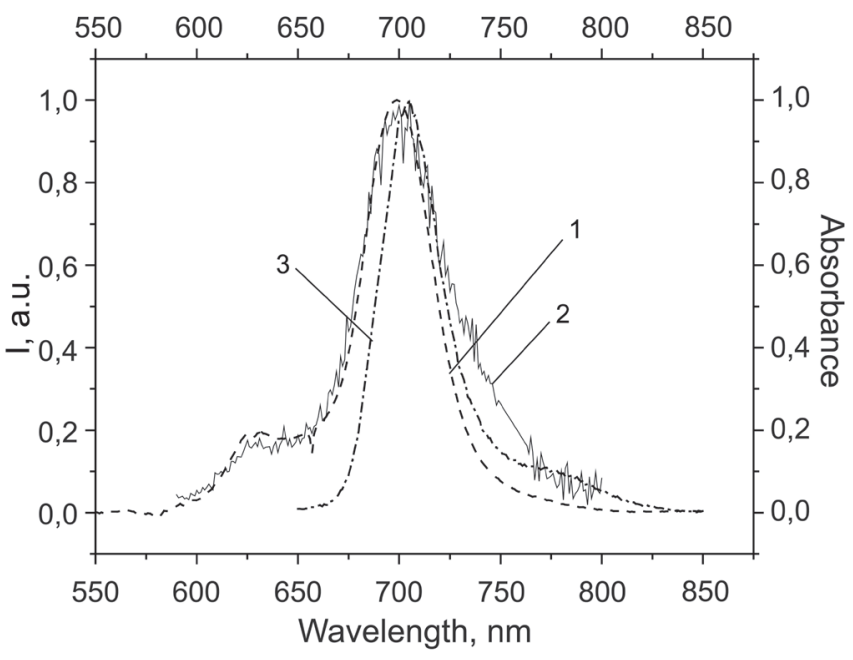

Figure 3. The normalized absorption (1) excitation (2) and emission (3) spectra of 4P-250/SiPc.
It is seen that the emission spectrum is close to the mirror image of the long wavelength absorption band. The emission spectrum with the main maximum at 703 $\mathrm{nm}$ and the shoulder at about $775 \mathrm{~nm}$ corresponding to the vibrational satellite was observed. Stokes shift was about 5 $\mathrm{nm}$. The fluorescence excitation spectrum showed all main phthalocyanine absorption bands.

As Table 1 indicates, the unbound $\mathrm{SiPcChol}_{8}$ and anchored $\mathrm{SiPcChol}_{7}$ have the same fluorescence maxima. However, due to the suspension light scattering it was impossible to estimate the number of photons absorbed by sensitizer and evaluate the fluorescence quantum yields. Relative measurements were performed, the effect of spacer length upon fluorescence efficiency was not observed. It should be mentioned that yield $\Phi_{\mathrm{F}}$ for free $\mathrm{SiPcChol}_{8}$ was found to be relatively low, 0.06 , and for attached $\mathrm{SiPcChol}_{7}$ those cannot surpass this value.

Energy transfer between the triplet state of photosensitizer and ground state molecular oxygen leads to the production of singlet oxygen, ${ }^{1} \mathrm{O}_{2}$, which is the key agent in the photodynamic action. It is essential to determine the efficacy of ${ }^{1} \mathrm{O}_{2}$ production.

Figure 4 illustrates one of the experiments on photosensitized bleaching of a singlet oxygen trap 1,3diphenylisobenzofuran (DPBF) in aqueous suspensions containing $0.2 \mathrm{M}$ SDS and $4 \mathrm{P}-250 / \mathrm{SiPc}$. It is seen that upon irradiation of the suspension in the spectral region absorbed by $\mathrm{SiPcChol}_{7}$, the absorbance of DPBF at the maximum $414 \mathrm{~nm}$ rapidly decreased. Absorbance of immobilized dye during these experiments remained unchanged. The quencher of singlet oxygen, sodium azide, markedly decreased the rate of photosensitized oxygenation of DPBF. These results prove the production of ${ }^{1} \mathrm{O}_{2}$ under excitation of heterogeneous sensitizer.

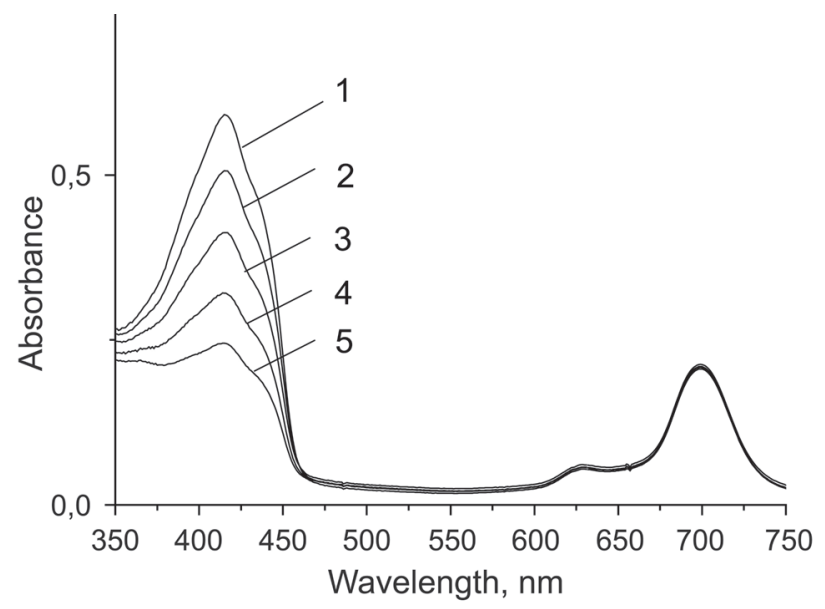

Figure 4. The change in the absorption spectrum of 1,3-diphenylisobenzofurun (DPBF) in 0.2 M SDS aqueous solution, containing suspended 4P-250/SiPc, under irradiation by light with $\lambda=710 \pm 25 \mathrm{~nm}$. Irradiation periods: $0,1,2,3$ and $4 \mathrm{~min}$ (curves 1-5, correspondingly).

It was found that unbound $\mathrm{SiPcChol}_{8}$ in aqueous solution sensitizes the singlet oxygen formation with $0.47 \pm 0.04$ quantum yield. This value is high and suggests sufficient efficacy for singlet oxygen generation by 
$\mathrm{SiPcChol}_{7}$ bound to silica gel. However, due to the light scattering it was impossible to estimate the singlet oxygen quantum yield for geterogeneous sensitizers. The rates of sensitized DPBF photobleaching in aqueous 0.2 M SDS were close in $250 / \mathrm{SiPc}, 750 / \mathrm{SiPc}$ and $250 / \mathrm{AlPc}$ series, and this result shows that length of linker has no appreciable impact upon efficacy of singlet oxygen production by attached sensitizer.

The photoinactivation of genetically engineered bioluminescent strain E. coli K-12 TG1 (biosensor) was used to test the photobactericidal activity of heterogeneous sensitizers. This biosensor system known under the trade mark Ecolum $^{[17]}$ is widely used for the assessment of the toxicity of various compounds. It was shown that photodynamic killing of bacterial cells caused reduction of the bioluminescence intensity. This effect was found to correlate with the colonyforming ability of the biosensor cells. Thus, bioluminescence quenching serves also as a rapid and simple test for the assessment of the photocytotoxicity of dyes. ${ }^{[17]}$

We observed that incubation of bacteria with the heterogeneous sensitizers under investigation in the absence of light did not lead to reduction of bioluminescence, evidencing that the sensitizers are nontoxic in the dark. Irradiation of biosensor suspensions in the presence of phthalocyanine-free silica gel did not affect bioluminescence either. At the same time, irradiation of bacteria in the presence of the heterogeneous photosensitizers synthesized in this work rapidly suppressed bioluminescence as a result of photobactericidal effect.

To compare photosensitizing activity of heterogeneous photosensitizers with different spacer chain we used samples with the same concentration $4 \mathrm{~g} \cdot \mathrm{L}^{-1}, 5 \mu \mathrm{mol} \cdot \mathrm{g}^{-1}$ of attached phthalocyanine, corresponding to $20 \mu \mathrm{M}$ of active phase. This allowed to avoid differences in sample's optical density and aligned irradiation conditions. Results on the biosensor photoinactivation by heterogeneous sensitizers under investigation are shown in Table 2. Figure 5 as an example illustrates the effect of spacer length on photobactericidal activity of the SiPcChol ${ }_{7}$, supported on Diasorb-250 amine. It is seen that the photobactericidal function of the supported $\mathrm{SiPcChol}_{7}$ is markedly increased along with length of spacer. The results with $\mathrm{SiPcChol}_{7}$ attached to Diasorb750 amine and $\mathrm{AlPc}(\mathrm{SPh})_{4} \mathrm{Chol}_{7}$ on Diasorb-250 amine also reveal that a longer spacer chain is preferred for the immobilization of the photodynamic sensitizers onto the surface

Table 2. The biosensor photoinactivation by heterogeneous sensitizers $\left(4 \mathrm{~g} \cdot \mathrm{L}^{-1}\right)$ and white light in dose $180 \mathrm{~J} / \mathrm{cm}^{2}$ (1 h irradiation) measured by bioluminescent test.

\begin{tabular}{cc}
\hline Sensitizer & Bioluminescence, $\%$ to dark control \\
\hline $1 \mathrm{P}-250 / \mathrm{SiPc}$ & $77 \pm 6$ \\
$2 \mathrm{P}-250 / \mathrm{SiPc}$ & $52 \pm 5$ \\
$4 \mathrm{P}-250 / \mathrm{SiPc}$ & $23 \pm 4$ \\
$1 \mathrm{P}-750 / \mathrm{SiPc}$ & $48 \pm 4$ \\
$2 \mathrm{P}-750 / \mathrm{SiPc}$ & $25 \pm 3$ \\
$4 \mathrm{P}-750 / \mathrm{SiPc}$ & $10 \pm 2$ \\
$1 \mathrm{P}-250 / \mathrm{AlPc}$ & $71 \pm 6$ \\
$2 \mathrm{P}-250 / \mathrm{AlPc}$ & $43 \pm 4$ \\
\hline
\end{tabular}

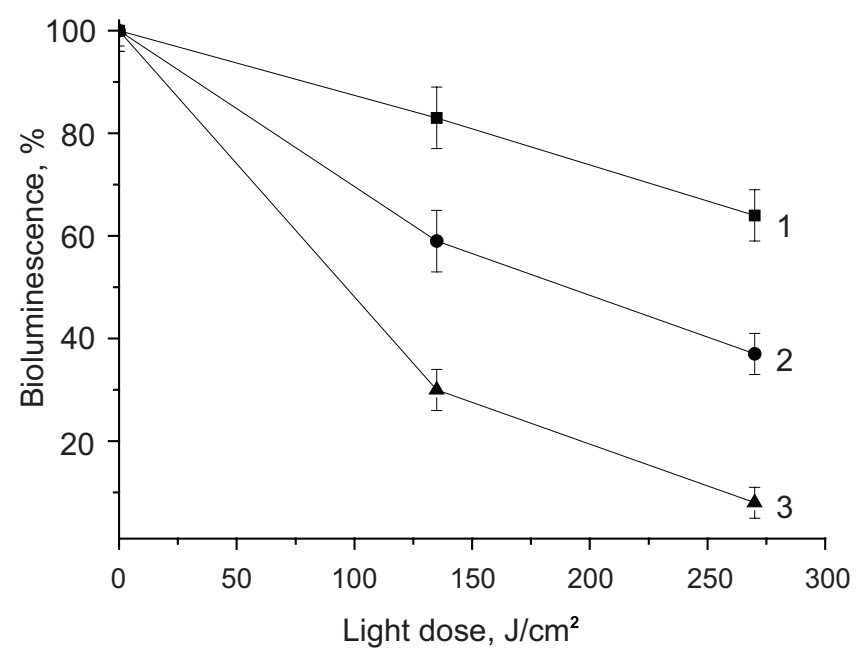

Figure 5. Quenching of E. coli K-12 TG1 (biosensor Ecolum) bioluminescence under irradiation by white light $\left(50 \mathrm{~mW} / \mathrm{cm}^{2}\right)$ in the presence of heterogeneous photosensitizers $\left(4 \mathrm{~g} \cdot \mathrm{L}^{-1}\right): 1-1 \mathrm{P}-$ 250/SiPc; 2 - 2P-250/SiPc; 3 - 4P-250/SiPc.

of solid support. The longer spacer chains enable the surface immobilized photosensitizers to act with a higher freedom, which is more similar to their free analogs in solution.

The effect of length of spacer between phthalocyanine and silica gel support upon photostability of the photobactericidal action of heterogeneous sensitizers was tested with 1P-250/AlPc and 2P-250/AlPc as an example. The experiments with several cycles of sensitizer usage were carried out as follows. After the irradiation of a suspension of bioluminescent bacteria containing a photosensitizer with light in a dose of $180 \mathrm{~J} / \mathrm{cm}^{2}$, the supernatant liquid with treated bacteria was separated and fresh bacteria were added to the sediment of the heterogeneous sensitizer. The suspension was incubated again for $10 \mathrm{~min}$ upon stirring and then irradiation was repeated. Figure 6 provides

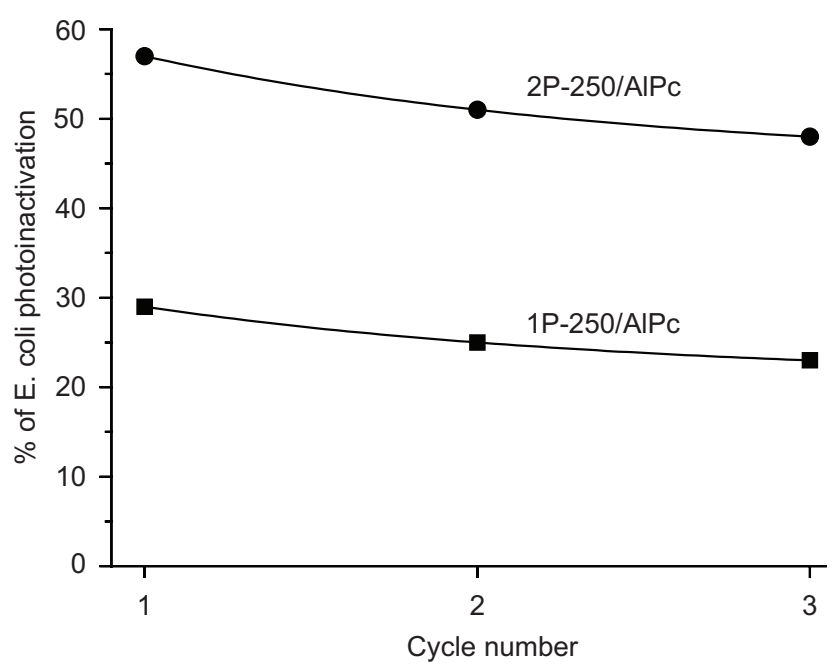

Figure 6. The effect of cycle number upon efficacy of $E$. coli K-12 TG1 photoinactivation under irradiation by white light (dose of $180 \mathrm{~J} / \mathrm{cm}^{2}$ per cycle) in the presence of heterogeneous photosensitizers 1P-250/AlPc and 2P-250/AlPc $\left(4 \mathrm{~g} \cdot \mathrm{L}^{-1}\right)$. 
additional evidence of high magnification of $E$. coli $\mathrm{K}-12$ TG1 photoinactivation efficacy along with spacer length and illustrates a stability of the photobactericidal action of the heterogeneous sensitizers 1P-250/AlPc and 2P-250/ AlPc in three cycles of use. A slow decline of heterogeneous sensitizer activity in $E$. coli K-12 TG1 photoinactivation (by $5-7 \%$ after each cycle of irradiation) regardless of spacer length was observed.

\section{Conclusions}

New heterogeneous sensitizers have been synthesized by grafting of phthalocyanines to aminopropyl silica by spacers of variable length. The heterogeneous structures with longer spacers were synthesized by initial treatment of aminopropyl groups on silica gel with 3-bromopropylamine hydrobromide to add another propyleneimine fragment. This procedure may be reiterated to obtain any number of propyleneimine units in the chain. Then polychloromethylated phthalocyanine is chemically bounded to spacer amino groups. In the present work silicon phthalocyanine or aluminum tetra-(3-phenylsulphanyl)phthalocyanine with eight chloromethyl substituents were used for grafting. Finally, the reaction of the immobilized chloromethyl substituted phthalocyanines with $N, N$-dimethylaminoethanol yielded derivatives with positively charged $N$-(2-hydroxyethyl)- $N, N$ dimethylammonium-methyl groups. Thus, a set of heterogeneous sensitizers with positively charged photosensitizing agents tethered to silica by spacers of variable length have been synthesized.

The effect of spacer length upon absorption and emission spectra as well as on efficacy of singlet oxygen generation by grafted phthalocyanines was not observed. However, the photobactericidal function of the supported phthalocyanines was markedly increased along with length of spacer. Also, influence of spacer length upon stability of the photobactericidal action of heterogeneous sensitizers was not found.

Hence, present study shows great advantage of heterogeneous photosensitizers with long spacer between sensitizing dye and support in bacteria photoinactivation. Such materials could find different applications, and their investigations are in progress.
Acknowledgements. The reported study was partially supported by RFBR, research project Nos. 13-03-00667a and 13-03-12094.

\section{References}

1. Raab O. Z. Biol. 1900, 39, 524-546.

2. Valduga G., Bertoloni G., Reddi E., Jori G. J. Photochem. Photobiol. B: Biol. 1993, 21, 81-86.

3. Kuznetsova N. Sensitization of Singlet Oxygen Formation in Aqueous Media. In: Photosensitizers in Medicine, Environment, and Security (Nyokong T., Vefa A., Eds.). Springer Science, 2012. p. 271-318.

4. Kuznetsova N.A., Kaliya O.L., Vorozhtsov G.N. J. Haz. Mater. 2007, 146, 487-491.

5. Patent RF. 1992; N 2036235.

6. Kuznetsova N.A., Yuzhakova O.A., Strakhovskaya M.G., Shumarina A.O., Kozlov A.S., Krasnovsky A.A., Kaliya O.L. J. Porphyrins Phthalocyanines 2011, 15, 718-726.

7. Nedachin A.E., Kuznetsova N.A., Dmitrieva R.A., Doskina T.V., Yuzhakova O.A., Kaliya O.L., Maksimkina T.N. Gigiena $i$ Sanitariya 2011, N 6, 35-38 (in Russ.).

8. Kuznetsova N.A., Yuzhakova O.A., Kozlov A.S., Krasnovskii A.A., Strakhovskaya M.G., Kaliya O.L. Nanotechnologies in Russia 2013, 8, 122-128.

9. Kuznetsova N.A., Yuzhakova O.A., Nedachin A.E., Dmitrieva R.A., Doskina T.V., Maksimkina T.N., Kaliya O.L. J. Porphyrins Phthalocyanines 2013, 17, 772-777.

10. Zhu J., Sun G. J. Mater. Chem. 2012, 22, 10581-10588.

11. Nardello V., Aubry J-M. Tetrahedron Lett. 1997, 38, 7361-7364.

12. Derkacheva V.M., Lukyanets E.A. Zh. Obshch. Khim. 1980, 50, 2313-2318 (in Russ.).

13. Patent RF. 2010; N 2405785.

14. Kuznetsova N.A., Shevchenko E.N., Makarov D.A., Slivka L.K., Solovyova L.I., Kaliya O.L., Lukyanets E.A. J. Porphyrins Phthalocyanines 2012, 16, 1244-1251.

15. Makarov D.A., Yuzhakova O.A., Slivka L.K., Kuznetsova N.A., Negrimovsky V.M., Kaliya O.L., Lukyanets E.A. J. Porphyrins Phthalocyanines 2007, 11, 586-595.

16. Krasnovsky A.A., Roumbal Y.V., Strizhakov A.A. Chem. Phys. Lett. 2008, 458, 195-199.

17. Strakhovskaya M.G., Zarubina A.P., Zhuhovitsky V.G., Mironov A.F., Rubin A.B. Dokl. Biochem. Biophys. 2004, 396, 177-180.

18. Kuznetsova N.A., Gretsova N.S., Derkacheva V.M., Kaliya O.L., Lukyanets E.A. J. Porphyrins Phthalocyanines 2003, 7, $147-154$ 